Wilk, M., Żabiński, M. (2019). „Małopolski Tele-Anioł”. Opis przypadku innowacji społecznej w obszarze usług teleopiekuńczych dla seniorów. W: N. Laurisz, A. Pacut (red.). Ekonomia Społeczna. Innowacyjność społeczna w Polsce (s. 60-71). Kraków: Uniwersytet Ekonomiczny w Krakowie. https://doi.org/10.15678/ES.2019.2.06

\title{
"Małopolski Tele-Anioł". Opis przypadku innowacji społecznej w obszarze usług teleopiekuńczych dla seniorów
}

\author{
Monika Wilk, Michał Żabiński
}

\begin{abstract}
Streszczenie: Celem opracowania jest omówienie innowacji społecznej w obszarze systemów teleopieki dla seniorów, współtworzonych przez organizacje pozarządowe. Na przykładzie projektu „Małopolski Tele-Anioł" zaprezentowany został potencjał organizacji trzeciego sektora do aktywnego udziału w procesie świadczenia usług społecznych. Metodą badawczą wykorzystaną w badaniach jest opis wybranego przypadku, w oparciu o dostępną dokumentację projektową. Na podstawie analizy działań podejmowanych w tym obszarze na terenie Polski, przy wykorzystaniu środków finansowych dostępnych w ramach Regionalnych Programów Operacyjnych na lata 2014-2020, wybrano przykład, wyróżniający się swoją skalą. W pracy omówiono innowację społeczną w postaci usługi teleopiekuńczej dla seniorów, w proces świadczenia której zaangażowane są organizacje pozarządowe. Przedstawiona została kwestia podziału ról i zadań instytucji reprezentujących różne sektory, w tym podmiotów społecznych, w procesie świadczenia tej usługi. Projekt ten jest argumentem na rzecz rozszerzenia zaangażowania organizacji pozarządowych w proces świadczenia usług społecznych
\end{abstract}

Słowa kluczowe: innowacje społeczne; teleopieka; bransoletka SOS; NGO; organizacje pozarządowe; usługi społeczne; seniorzy

Kody JEL: $\mathrm{H} 75 ; \mathrm{O} 35$

\section{Wprowadzenie}

Współczesna, złożona rzeczywistość społeczno-ekonomiczna narzuca konieczność współpracy przedstawicieli wszystkich trzech sektorów działalności społeczno-gospodarczej, w ramach działań o charakterze społecznym. Funkcje te pierwotnie realizowane były przez administrację samorządową. Wyczerpywanie się starych modeli działania - opartych o sektor publiczny, lub też zlecanie realizacji usług publicznych podmiotom zewnętrznym - stworzyło przestrzeń do kooperacji pomiędzy organizacjami społecznymi, przedsiębiorstwami prywatnymi i administracją samorządową w ramach wspólnych działań na rzecz adresowania wyzwań i problemów społecznych (Sempruch, 2012, s. 34). Współpracę trzech sektorów, określaną terminem welfare mix, cechuje rosnący udział roli organizacji prywatnych i społecznych w procesie świadczenia usług publicznych, tradycyjnie przypisywanych sektorowi publicznemu (tamże, s. 35). Model ten, oparty o innowacje społeczne, staje się głównym sposobem kreowania przestrzeni społecznej oraz świadczenia usług publicznych, w tym społecznych. 
Innowacje społeczne są zarówno nowym sposobem realizacji polityki społecznej państwa, jak i drogą do wyznaczania nowych działań i ich standardów w obszarze tej polityki - tworzenia nowej wartości (Mulgan i Pulford, 2011, s. 17-22). Przykładem usługi społecznej, realizowanej w formule welfare mix jest teleopieka senioralna, będąca obecnie w Polsce w fazie rozwoju (Chmielewski i in., 2017, s. 3; Kilian i in., 2018, s. 147). W obszarze tych usług - m.in. dzięki środkom finansowym pochodzącym z Europejskiego Funduszu Społecznego, w latach 2014-2020 - polskie samorządy zaczęły wdrażać innowacyjne rozwiązania na szerszą skalę. W oparciu o analizę dostępnych materiałów dotyczących projektów realizowanych w ramach środków Regionalnych Programów Operacyjnych (RPO) zaplanowanych na lata 2014-2020, wybrany został projekt „Małopolski Tele-Anioł”. Projekt jest realizowany w ramach RPO województwa małopolskiego.

Celem opracowania jest przedstawienie innowacji społecznej w obszarze systemów teleopieki dla seniorów, współtworzonych przez organizacje pozarządowe, na przykładzie projektu „Małopolski Tele-Anioł”. Część pierwsza poświęcona jest teorii innowacji i charakterystyce innowacji społecznych. Dalej przedstawiono kwestię innowacji w teleopiece. Kolejna część tekstu zawiera opis metodologii badania. W czwartej sekcji omówiono projekt „Małopolski Tele-Anioł", jako przykład innowacji społecznej. Tekst kończą konkluzje, zawierające m.in. kierunki dalszych badań.

\section{Od innowacji przemysłowej do innowacji społecznej}

Austriacki ekonomista Joseph Schumpeter w swojej teorii dynamiki gospodarki kapitalistycznej zwrócił uwagę na rolę i znaczenie innowacji jako czynnika produkcji, który napędza rozwój systemu kapitalistycznego (Glapiński, 2012, s. 4). Innowacje (łac. innovativo - odnowienie) (Sobol, 1997, s. 60) w myśli Schumpetera to nowe kombinacje środków produkcji dotyczące sytuacji „wprowadzenia nowego towaru lub nowego gatunku towaru, wprowadzenia nowej metody produkcji, otwarcie nowego rynku zbytu, zdobycie nowego źródła surowców lub półfabrykatów, przeprowadzenie nowej organizacji jakiegoś przemysłu" (Schumpeter, 1960, s. 131). Schumpeter zajmował się przede wszystkim innowacjami przemysłowymi i ich oddziaływaniem na rozwój gospodarczy. Kreatywność w jego ujęciu była cechą przedsiębiorców, dzięki której możliwy był rozwój gospodarki, rozumiany jako zmiana strukturalna, jakościowa (Glapiński, 2012, s. 4).

Teoria Schumpetera ma charakter podażowy - innowacje są dziełem przedsiębiorców, którzy inspirują i kreują rynek. Tymczasem innowacje można postrzegać w znacznie szerszym kontekście. Według Petera Druckera (1992, s. 14), jednego z najwybitniejszych teoretyków zarządzania XX w., innowacja to „...świadoma korzystna zmiana wynikająca z potrzeb lub systematycznej obserwacji środowiska zewnętrznego. Jest ona celową i skoncentrowaną pracą, która wymaga wiedzy i pomysłowości. Bodźcem do powstania innowacji nie koniecznie musi być czynnik techniczny, lecz zwykła obserwacja rynku". Podobne rozumienie innowacji odnajdujemy w definicji przyjętej przez Organizację Współpracy Gospodarczej i Rozwoju (OECD) oraz Europejski Urząd Statystyczny w Podręczniku Oslo (Oslo Manual), według której innowacja „to wdrożenie nowego lub znacząco udoskonalonego produktu (wyrobu lub usługi) lub procesu, nowej metody marketingowej lub nowej metody organizacyjnej w praktyce gospodarczej, organizacji miejsca pracy lub stosunkach z otoczeniem." Innowacją może być więc zarówno zupełnie nowe rozwiązanie, które dany podmiot wdraża jako pierwszy, w ramach któregoś z czterech obszarów, lub też wdrożenie rozwiązania już istniejącego, ale nowego 
z perspektywy organizacji wdrażającej, lub też udoskonalenie rozwiązania już stosowanego. Co więcej, definicja ta wskazuje na cztery główne typy innowacji. Jest to typ: produktowy, procesowy, marketingowy i organizacyjny (OECD, 2008, s. 48-50). Definicja zawarta w Podręczniku Oslo jednocześnie wyjaśnia czym jest innowacja, ale też przedstawia podstawową typologię innowacji. W typologii tej nie zostały jednak wyróżnione innowacje społeczne jako osobna kategoria.

Na społeczny wymiar innowacji zwrócono uwagę w latach 90. XX w. (Wronka-Pośpiech, 2015, s. 124-125). Główną przyczyną wyodrębnienia ich jako osobnej kategorii w ramach innowacji, był wzrost natężenia problemów społecznych, środowiskowych i demograficznych. Dla zaadresowania tych wyzwań szczególne znaczenie ma rola podmiotów społecznych, ze względu na ich szczególną umiejętność odzwierciedlenia otaczającej nas rzeczywistości społeczno-gospodarczej, a także tempa i zakresu jej zmian (Olejniczuk-Merta, 2013, s. 21-34). Jest więc to specyficzny rodzaj „....innowacyjnych działań i usług, które są motywowane celem zaspokojenia potrzeb społecznych i które są rozpowszechniane głównie przez organizacje, których podstawowym celem są cele społeczne" (Mulgan, 2006, s. 146). W ramach międzynarodowego projektu The Theoretical, Empirical and Policy Foundations for Building Social Innovation in Europe (TEPSIE), innowacje społeczne zdefiniowano jako nowe rozwiązanie, które pozwala na zaspokojenie pewnej potrzeby społecznej w nowy, lepszy sposób niż dotychczasowe rozwiązania, a jednocześnie tworzy nowe lub usprawnione funkcje i relacje oraz lepiej wykorzystuje dostępne zasoby i środki. Definicja ta wydaje się adekwatna do oceny prezentowanego w tym opracowaniu przykładu pod kątem jego innowacyjności.

Innowacje społeczne to - w świetle wyżej przytoczonych definicji - takie nowatorskie przedsięwzięcia, które odnoszą się do przedsiębiorczości społecznej, przedsiębiorstw społecznych oraz innowacji technologicznych, tworzących społeczną odpowiedzialność i przynoszących korzyści społeczne (Knop i in., 2014, s. 240; Sempruch, 2012, s. 34). Tym samym innowacje społeczne nie tylko rozwiązują problemy ważne dla obywateli, ale jednocześnie zwiększają zdolność społeczeństwa do działania (Kwaśnicki, 2014, s. 28). Są również sposobem edukacji i budowania społeczeństwa obywatelskiego. Wypełniają pewnego rodzaju „lukę kulturową" pomiędzy rozwojem technicznym i kulturowym (Knop i in., 2014, s. 240). Ich głównym celem jest przede wszystkim zaspokojenie potrzeb, których nie jest w stanie zaspokoić rynek, a więc problemów takich jak: wykluczenie, narastające nierówności, starzenie się społeczeństw, bezrobocie czy zanieczyszczenie środowiska i zmiany klimatyczne (Mulgan, 2006, s. 147). O społecznym charakterze innowacji decydują jej specyficzne cechy, takie jak (Olejniczuk-Merta, 2013, s. 26):

- cel społeczny (związany z podniesieniem jakości życia społeczeństwa lub jego części określonej grupy społecznej);

- z góry określony przebieg (wymagający zaangażowania kapitału społecznego);

- przewidywany efekt społeczny (w postaci korzystnej zmiany sytuacji, zaadresowania wybranego problemu społecznego).

Bodźcem dla innowacji społecznej jest chęć rozwiązywania narastających problemów społecznych i podniesienie jakości życia społeczeństwa jako całości. Co więcej, „innowacja społeczna, musi być zrównoważona, co oznacza, że powinna sprostać wyzwaniom gospodarczym i środowiskowym. Ma minimalizować szkodliwy wpływ na środowisko naturalne, który wywołany został przez jej rozwój" (Wyrwa, 2014, s. 42). Na swój sposób innowacje społeczne są elastyczne, ponieważ mogą przybierać różne formy (Wronka-Pośpiech, 2015, s. 129), takie jak: 
- nowe modele biznesowe - franczyza społeczna, wykorzystanie strategii just-in-time (JIT) przy wyzwaniach społecznych;

- nowe rynki - Fair Trade (sprawiedliwy handel), banki czasu;

- nowe formy organizacyjne - przedsiębiorstwa społeczne;

- nowe platformy - nowe modele opieki nad osobami przewlekle chorymi;

- nowe procesy - model współpracy peer-to-peer, crowdsourcing;

- nowe usługi - mikrokredyty, bankowość mobilna;

- nowe produkty - technologie wspomagające ludzi niepełnosprawnych (np. syntezatory głosu).

Innowacje społeczne realizowane są poprzez włączanie różnych podmiotów (przedsiębiorstwa, organizacje pozarządowe, społeczeństwo itp.) w wykreowanie nowego rozwiązania z zakresu polityk społecznych, sprzyjającego wszystkim zainteresowanym. Wyróżniamy pięć podstawowych obszarów występowania tego typu innowacji (Wronka-Pośpiech, 2015, s. 125), są to:

- transformacja społeczna,

- model zarządzania organizacją,

- przedsiębiorczość społeczna,

- rozwój nowych produktów, usług i programów,

- model zarządzania, wzmocnienia pozycji i zwiększenia zdolności instytucji społecznych.

Proces tworzenia innowacji społecznych podzielić można na poszczególne etapy realizacji. Popularny model procesu innowacji społecznej (Murray i in., 2010, s. 12-13) wyróżnia sześć faz przebiegu tego procesu. Pierwsza faza - prompts, inspirations and diagnoses (podpowiedzi, inspiracje, diagnozy) - to etap wstępny, identyfikowania potrzeb i rozpoznania problemu. Druga faza - proposals and ideas (propozycje i pomysły) - obejmuje generowanie i gromadzenie pomysłów, które odpowiadają wcześniej zidentyfikowanym potrzebom. Trzecia faza - prototyping and pilots (prototypowanie i pilotaż) - testowanie innowacji w praktyce, wraz z możliwością wprowadzenia modyfikacji, w celu usprawnienia rozwiązania. Czwarta faza - sustaining (utrwalenie) - służy popularyzacji innowacji, która przeszła pozytywnie fazę pilotażu. Przedostania, piąta faza - scaling and diffusion (skalowanie i dyfuzja) - to etap upowszechnienia, ekspansji innowacji. Szósta faza - systemic change (zmiana systemowa) - której celem jest zmiana w sposobie myślenia, postrzegania i działania społeczeństwa oraz pozostałych podmiotów, a więc systemowa zmiana podejścia do danego zagadnienia. W efekcie tego innowacje społeczne kształtują społeczeństwo i gospodarkę.

Tworzenie innowacji społecznych uzależnione jest od zaangażowania wielu podmiotów. Udział różnych grup społecznych, instytucji publicznych oraz biznesowych, pozwala na osiągnięcie efektu synergii, uwspólnianie korzyści, tym samym zaspokojenia potrzeb ogółu społeczeństwa i rozwiązanie problemów społecznych.

\section{Innowacje w teleopiece}

Rynek usług teleopiekuńczych w Polsce jest silnie zróżnicowany i znajduje się w fazie dynamicznego rozwoju (Chmielewski i in., 2017, s. 5; Kilian i in., 2018, s. 147). Usługi te świadczone są w oparciu o rozwiązania technologiczne umożliwiające szeroko pojęte wsparcie zdalne. W ramach usług teleopiekuńczych wyróżniamy rozwiązania oparte o: urządzenia alarmowe, predykcyjne, prewencyjne, lokalizatory, czy też różnego typu czujniki podnoszące poziom bezpieczeństwa w mieszkaniach użytkowników (np. czujniki dymu, czadu) (Chmielewski i in., 2017, 
s. 6, 9; Kilian i in., 2018, s. 151-153). Rozwiązania te są znacznie popularniejsze i wykorzystywane na szeroką skalę w krajach Europy Zachodniej, zwłaszcza w krajach anglosaskich (Deloitt, 2015; Pawlińska-Chmara, 2016, s. 151) czy państwach skandynawskich (Kilian i in., 2018, s. 151-154).

Innowacją produktową w zakresie teleopieki jest wykorzystanie opasek lub bransoletek wyposażonych w nowoczesne czujniki teledetekcji oraz technologie komunikacji bezprzewodowej. Rozwiązanie to zwane potocznie „bransoletkami życia” lub "opaskami SOS”, jest innowacyjnym wykorzystaniem istniejącej już technologii (z zakresu technologii ubieralnej Wearables), przeznaczonej pierwotnie na potrzeby monitorowania poziomu aktywności fizycznej, dla nowej grupy docelowej, wraz z zmodyfikowaniem rozwiązania do jej specyficznych potrzeb.

Teleopieka oparta na rozwiązaniach mobilnych, takich jak opaski monitorujące i jednocześnie umożliwiające komunikację dwustronną, jest innowacją, której tempo popularyzacji jest zróżnicowane. Na podstawie skali wdrożeń można uznać, że w krajach takich jak Wielka Brytania, Francja czy Niemcy jest to rozwiązanie znajdujące się obecnie w fazie piątej według modelu Murray'a, Caulier-Grice'a i Mulgana (2010, s. 12-13) czyli fazie skalowania i dyfuzji. Rozwiązanie to jest tam obecnie na etapie upowszechnienia się innowacji. Natomiast w Polsce, biorąc pod uwagę skalę rozumianą jako liczbę osób objętych pomocą w ramach poszczególnych przedsięwzięć, innowacja ta znajduje się w fazie trzeciej - pilotażu.

W sytuacji starzejącego się społeczeństwa teleopieka jest niezbędnym uzupełnieniem dla tradycyjnej opieki fizycznej (Pawlińska-Chmara, 2016, s. 153). Warunkiem koniecznym kreowania innowacji społecznych jest występowanie sprzyjających okoliczności, odpowiedniego klimatu do ich rozwoju, obejmującego kwestie otoczenia formalno-prawnego (Kwaśnicki, 2014, s. 40-42), ale też kwestie finansowe. Dlatego też przedsięwzięcia takie jak program RPO są szansą na rozwój i upowszechnienie się tego typu innowacji. Środki te pozwalają samorządom na podejmowanie nowych wyzwań w zakresie działań na rzecz rozwoju świadczonych usług społecznych. Usługi teleopiekuńcze wymagają bowiem stworzenia stosownych systemów teleinformatycznych oraz odpowiedniego sprzętu, na który wielu samorządów, bez zewnętrznego wsparcia, nie byłoby stać. Dlatego też autorzy postanowili przyjrzeć się projektom teleopiekuńczym realizowanym właśnie w ramach RPO.

\section{Metoda badawcza}

Studium przypadku jako jakościowa metoda badawcza, służy lepszemu zrozumieniu zachodzącego procesu, poprzez analizę wybranego przypadku (Wójcik, 2013). Metoda ta jest wykorzystywana dla potrzeb udzielania odpowiedzi na pytania mające charakter empiryczny, dotyczących tego "kto", "co", "jak", "gdzie" lub „dlaczego", a więc pytań odnoszących się do kwestii przyczyn i uwarunkowań badanego fenomenu (Yin, 2009, s. 8). Niniejszy tekst nie stanowi pełnoprawnego studium przypadku, lecz jest próbą przybliżenia interesującego przykładu innowacji społecznej, w oparciu o dostępne na temat tego projektu publikacje i materiały projektowe. "Małopolski Tele-Anioł" to pilotaż wykorzystania nowoczesnych rozwiązań z zakresu technologii informacyjno-komunikacyjnych dla celów wsparcia samotnych, niesamodzielnych osób, zastosowanych na skalę całego województwa.

Autorzy opracowania, opierając się na analizie dostępnych materiałów, pokazują przykład innowacji społecznej, jaką jest system teleopieki dla seniorów oparty o elektroniczną opaskę umożliwiającą zdalne monitorowanie stanu zdrowia seniora. Co więcej usługa ta jest współtworzona przez samorząd, organizacje pozarządowe i przedsiębiorstwo prywatne. Przeprowa- 


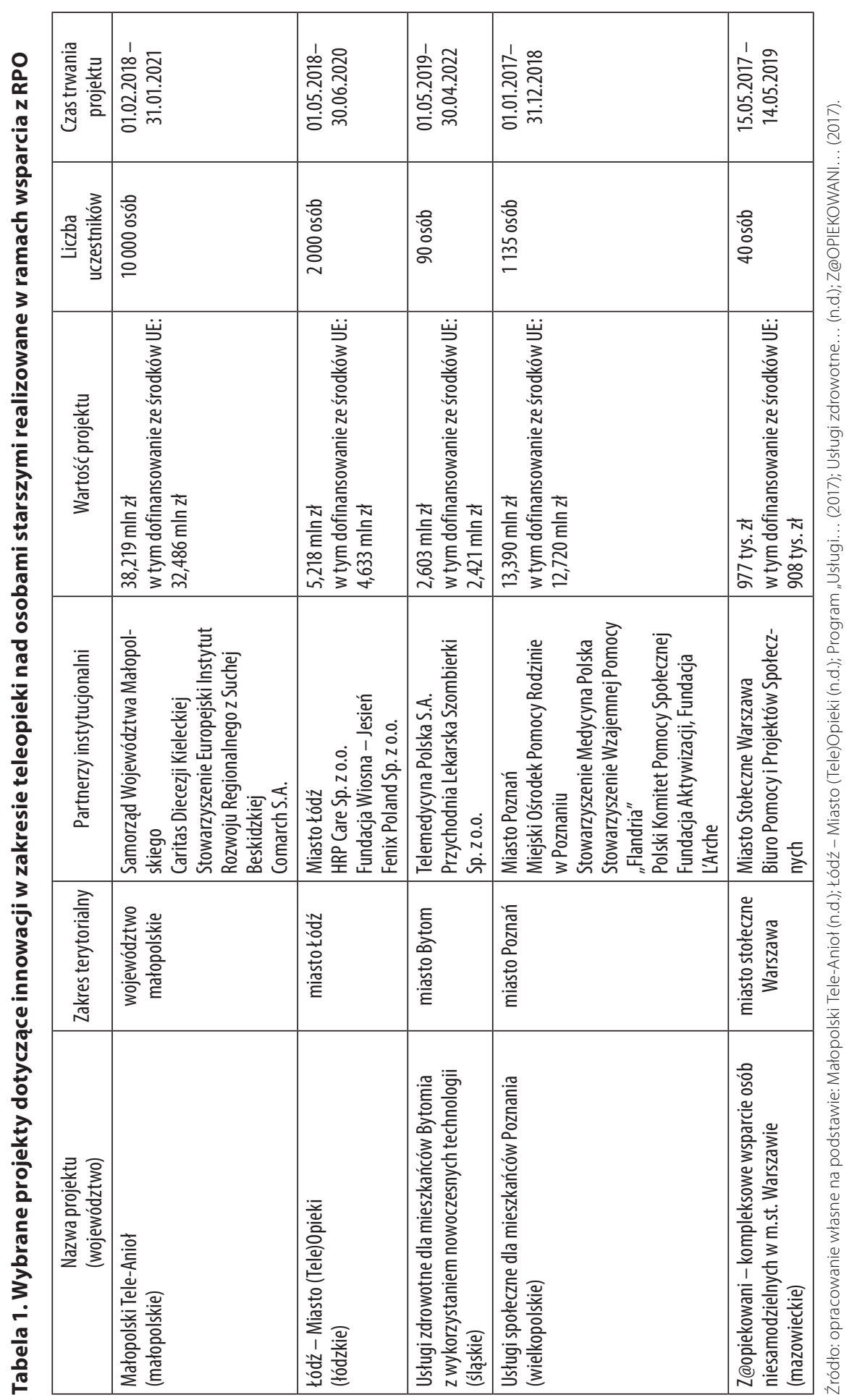


dzona analiza ma na celu wskazanie potencjału organizacji pozarządowych do włączania się w proces świadczenia nowoczesnych i innowacyjnych usług społecznych. Tym samym autorzy, w myśl definicji Yin, starają się wskazać odpowiedzi na pytania "kto" i „jak", w odniesieniu do wprowadzania innowacji społecznych w ramach usług teleopiekuńczych, posiłkując się przykładem „Małopolskiego Tele-Anioła”. Projekt ten został wybrany jako przykład omawianej innowacji w oparciu o analizę tego typu rozwiązań, aktualnie wdrażanych w Polsce w ramach RPO. Informacje na temat projektów uzyskane zostały poprzez wyszukiwanie informacji na stronach internetowych wszystkich RPO w Polsce. Badanie przeprowadzono w okresie październik - grudzień 2019 r. Przegląd informacji zawartych na stronach RPO dotyczył projektów związanych z teleopieką, a w szczególności wykorzystujących rozwiązanie technologiczne w postaci opasek SOS.

W przypadku części województw nie znaleziono żadnych tego typu projektów, w ramach programów realizowanych ze środków RPO. Bazując na informacjach dostępnych na stronach internetowych RPO, autorzy zidentyfikowali 5 projektów (tabela 1).

W trakcie badań zidentyfikowano rozwiązania o podobnym charakterze, funkcjonujące w innych województwach niż te przedstawione w tabeli poniżej. Jednak nie były one realizowane w ramach RPO oraz cechowała je niewielka skala oddziaływania i liczba odbiorców (por. Chmielewski i in., 2017, s. 16-20).

Spośród zebranych przypadków "Małopolski Tele-Anioł" wyróżnia się tym, że jako jedyny posiada partnera wiodącego w postaci samorządu regionalnego, jak również charakteryzuje się największą skalą, zarówno pod względem liczby beneficjentów objętych wsparciem, jak i wielkości środków finansowych przeznaczonych na jego realizację. Dlatego też wydaje się być najciekawszym, wyróżniającym się przypadkiem, wartym głębszej, indywidualnej analizy.

\section{5. „Małopolski Tele-Anioł" - przykład innowacji społecznej w obszarze teleopieki dla seniorów}

Obecnie w Polsce mamy do czynienia z kryzysem demograficznym (Ciura i Szymańczak, 2012, s. 2-3; GUS, 2019, s. 16). O tym problemie świadczyć mogą przede wszystkim: ujemny przyrost naturalny, niski poziom współczynnika dzietności (poniżej 1,5), wysoki poziom średniego dalszego trwania życia i regresywny poziom piramidy płci i wieku - badany za pomocą współczynnika obciążenia demograficznego. Ponadto od pięciu lat utrwala się niekorzystny trend mierzony współczynnikiem obciążenia - maleje liczna osób w wieku przedprodukcyjnym przypadających na każde 100 osób w wieku produkcyjnym (30/100 w 2018 r.), a rośnie liczna osób w wieku poprodukcyjnym (35/100 w 2018 r.). Konsekwencją tej sytuacji, zarówno dla polskiej gospodarki, jak i społeczeństwa, jest malejący udział potencjalnych przyszłych zasobów, przy równoczesnym wzroście liczby osób, które w przyszłości będą korzystać ze świadczeń społecznych, wymagających wsparcia i opieki. Doprowadzi to do sytuacji, w której zabraknie osób młodych mogących się zająć, zapewnić opiekę seniorom (GUS, 2019, s. 16-35). Oznacza to przyszły wzrost obciążeń nakładanych na osoby pracujące na rzecz osób, które rynek pracy już opuściły. Skutki tego procesu będą miały ogromny wpływ na rozwój społeczno-gospodarczy. Ich odzwierciedlenie będzie widoczne przede wszystkim we wzroście kosztów opieki zdrowotnej i prowadzenia polityk społecznych (Kilian i in., 2018, s. 148).

Realizowany na terenie województwa małopolskiego projekt "Małopolski Tele-Anioł”, to przykład działania odpowiadającego na powyższe wyzwania demograficzne oraz mający na celu dbałość o jakość życia seniorów. Głównym celem projektu jest zapewnienie niesamodziel- 
nym Małopolanom opieki zdrowotnej oraz pomocy w życiu codziennym, dzięki zorganizowaniu systemu opieki z wykorzystaniem technologii informacyjno-komunikacyjnych. Beneficjentami tej usługi są osoby niesamodzielne ze względu na stan zdrowia, niepełnosprawność i wiek; wymagające opieki lub wsparcia w co najmniej jednej z podstawowych czynności dnia codziennego, do których zalicza się przygotowywanie i spożywanie posiłków, samodzielne robienie zakupów, sprzątanie, poruszanie się, wychodzenie z domu, ubieranie się, higienę osobistą itp. (Małopolski Tele-Anioł, n.d.). W ramach projektu realizowane jest wsparcie w postaci usług opiekuńczych oraz sąsiedzkich usług opiekuńczych w miejscu zamieszkania.

W realizacji projektu uczestniczą: jednostka samorządu regionalnego (koordynator projektu), podmioty społeczne oraz przedsiębiorstwo prywatne (spółka Comarch - jako dostawca rozwiązania technologicznego). Jest więc to projekt oparty o zasady synergii, w którym potencjał do innowacyjności pochodzący z sektora prywatnego, jest twórczo rozwijany i adaptowany na nowym rynku, dzięki zaangażowaniu podmiotów trzeciego sektora (tabela 2).

\section{Tabela 2. Zadania podmiotów w ramach projektu „Małopolski Tele-Anioł”}

\begin{tabular}{|l|c|c|c|c|}
\hline Podmiot & $\begin{array}{c}\text { Urząd Marszałkowski } \\
\text { Województwa } \\
\text { Małopolskiego }\end{array}$ & $\begin{array}{c}\text { Caritas Diecezji } \\
\text { Kieleckiej }\end{array}$ & $\begin{array}{c}\text { Stowarzyszenie } \\
\text { Europejski Instytut } \\
\text { Rozwoju Regionalnego }\end{array}$ & Comarch Sp.z o.0. \\
\hline Zadania & $\begin{array}{c}\text { koordynacja } \\
\text { i finansowanie }\end{array}$ & \multicolumn{2}{|c|}{$\begin{array}{c}\text { rekrutacja beneficjentów } \\
\text { uruchomienie centrum teleopieki } \\
\text { zapewnienie usług opiekuńczych }\end{array}$} & $\begin{array}{c}\text { dostawa sprzętu } \\
\text { i oprogramowania }\end{array}$ \\
\hline
\end{tabular}

Źródło: opracowanie własne na podstawie: Małopolski Tele-Anioł (n.d.).

Działania teleopiekuńcze koordynowane są przez Centrum Teleopieki, którego zadaniem jest zapewnienie bezpieczeństwa wszystkim uczestnikom, poprzez możliwość całodobowego przekazywania informacji o potrzebie wezwania pomocy w przypadku zagrożenia życia, zdrowia lub bezpieczeństwa (Małopolski Tele-Anioł, n.d.).

Beneficjentami systemu są osoby starsze, wymagające pomocy, często samotne. Wszystkie te uwarunkowania sprawiają, że osoby te narażone są na niebezpieczeństwo utraty zdrowia i życia, ze względu na brak możliwości wezwania na czas pomocy w razie wypadku w warunkach domowych. System oparty o opaskę SOS adresuje ten problem. Każdy z seniorów uczestniczących w projekcie nosi na nadgarstku specjalną bransoletkę, wyposażoną w zestaw czujników, kartę SIM oraz przycisk wezwania pomocy - po wciśnięciu którego dokonywane jest natychmiastowe połączenie z Centrum Teleopieki. Ratownicy medyczni po odebraniu zgłoszenia oceniają stopień zagrożenia i udzielają odpowiedniego wsparcia lub pomocy. Około 10 tys. użytkowników dedykowanych opasek ma możliwość całodobowego połączenia głosowego z Centrum, którego pracownikami są wykwalifikowani asystenci teleopieki, ratownicy medyczni oraz psychologowie. System opieki działa następująco (rysunek 1):

- W razie zaistnienia potrzeby pomocy, osoba samotna naciska guzik na opasce SOS i zostaje automatycznie połączona z Centrum Teleopieki. Połączenia w centrum odbierane są przez wykwalifikowanych ratowników medycznych, którzy pełnią funkcję pierwszego kontaktu.

- System automatycznie identyfikuje podopiecznego wraz z przekazaniem ratownikowi cyfrowej karty z najważniejszymi informacjami o tej osobie.

- Dyżurny odbierający połączenie w telecentrum ocenia sytuację i podejmuje odpowiednie działania w związku ze zgłoszonym problemem (udziela porad, wzywa służby ratunkowe). 
Warto dodać, że kontakt z osobą trwa do momentu udzielenia pomocy bądź rozwiązania problemu.

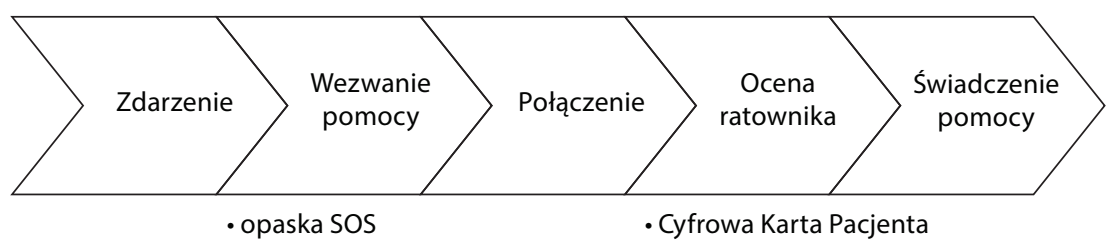

Rysunek 1. Schemat działania „Małopolskiego Tele-Anioła”

Źródło: opracowanie własne na podstawie: Małopolski Tele-Anioł (n.d.).

Innowacyjne rozwiązanie jakim jest opaska SOS, staje się innowacją społeczną, dzięki włączeniu jej w szerszą usługę, jaką jest system opieki z wykorzystaniem nowoczesnych technologii informacyjno-komunikacyjnych. Rudymentarnym elementem działania tego systemu jest zaangażowanie organizacji społecznych wspierających osoby niesamodzielne. Wprost wpisuje się to w definicję pojęcia innowacji, rozumianego jako nowe zastosowanie rozwiązania - jakim jest pomoc dla seniorów. Rozwiązanie to przyczynia się do zaspokojenia potrzeby społecznej, a w konsekwencji zapewnienia trwałej wartości społecznej (Flew i in., 2008, s. 10) w sposób bardziej efektywne niż dotychczasowe rozwiązania (Phills i in., 2008, s. 36; Sempruch, 2012, s. 34). Wartość generowana przez podmiotowe rozwiązanie, ma charakter ogólny - jest to wartość dla społeczeństwa jako całości, nie tylko dla bezpośredniego beneficjenta. Rozwiązanie to jest więc przykładem na to jaką rolę mogą pełnić organizacje pozarządowe w procesie rozwiązywania problemów społecznych.

Odnosząc się do definicji TEPSIE należy zwrócić uwagę na kluczowy element systemu, jakim jest zaangażowanie NGO's w postaci Caritas Diecezji Kieleckiej - Zespół Placówek Caritas w Proszowicach oraz Stowarzyszenia Europejski Instytut Rozwoju Regionalnego. Ich zaangażowanie sprawia, że projekt ten nie tylko jest nowym rozwiązaniem, które pozwala na zaspokojenie pewnej potrzeby społecznej w nowy sposób, ale też zapewnia lepsze wykorzystanie zasobów. Co więcej ze względu na specyfikę grupy docelowej organizacje te świadczą pomoc w procesie aplikacji do programu. To właśnie organizacje społeczne, specjalizujące się we wsparciu dla osób słabszych, wykluczonych, są predestynowane do świadczenia tego typu usług, gdyż ze względu na profil swojej działalności, podmioty te najlepiej znają potrzeby i ograniczenia beneficjentów i potrafią do nich dotrzeć. To dzięki tym organizacjom możliwe jest dotarcie do 10 tys. osób wymagających wsparcia. Analizując cechy innowacji społecznych, wyraźnie widoczne są: zarówno cel społeczny (wsparcie dla seniorów), zaangażowanie kapitału społecznego w przebiegu usługi (powierzenie NGO's kontaktu z seniorami), jak i przewidywany efekt społeczny (poprawa bezpieczeństwa i warunków życia samotnych seniorów). Innowacja ta jest zarówno nową platformą, nowym modelem opieki nad seniorami, jaki i nową usługą. Zgodnie z definicją obszarów występowania innowacji społecznej, według Wronki-Pośpiech (2015, s. 125), projekt „Małopolski Tele-Anioł” klasyfikuje się jako rozwój nowej usługi o charakterze społecznym.

Rozwiązanie jakim jest „Małopolski Tele-Anioł” pozwala zapobiegać alienacji społecznej osób starszych, zwiększa szansę na udzielenie niezbędnej pomocy medycznej oraz skraca czas jej udzielenia. Daje możliwość rozwoju osób starszych i stwarza przestrzeń na ich aktywizację i integrację ze społeczeństwem, jednocześnie zwiększa poczucie bezpieczeństwa samotnych 
seniorów. Pozwala włączyć seniorów w życie publiczne i zachęca do współdziałania. Rozwiązanie to jest przykładem innowacji społecznej zarówno jako nowa usługa, jak i nowy proces świadczenia usługi angażujący podmioty społeczne.

\section{Konkluzje}

Opieka nad starszymi, samotnymi osobami stanowi poważne wyzwanie dla samorządów. Działania takie wymagają zasobów kadrowych i finansowych, które przy narastającym problemie demograficznym przekraczają ograniczone możliwości samorządów. Dlatego też teleopieka wydaje się być rozwiązaniem, które pozwala lepiej odpowiedzieć na to wyzwanie. Stanowi wsparcie i uzupełnienie tradycyjnych form opieki nad osobami starszymi. Rezultatem takiego rozwiązania jest obniżenie kosztów związanych z zatrudnieniem opiekunów, zwiększenie niezależności osób starszych oraz poprawa ich jakości życia (Kilian i in., 2018, s. 156-158).

Wykorzystanie potencjału innowacji społecznych pozwala na wprowadzenie racjonalnych zmian w życiu publicznym, lepsze zaadresowanie wyzwań, problemów społecznych, dzięki nowemu, lepszemu zastosowaniu posiadanych zasobów. Bransoletka życia to produkt, a w szerszym kontekście - system opieki z wykorzystaniem nowoczesnych technologii informacyjno-komunikacyjnych, usługa, która spełnia Schumpeterowską definicję innowacji, stanowi innowację w postaci nowego gatunku już znanego towaru. Kluczowe znaczenie ma jej aspekt społeczny, bez którego nie byłaby możliwa realizacja jej celu głównego. Grupa docelowa to osoby starsze, często samotne i niesamodzielne, to dzięki organizacjom społecznym możliwe było dotarcie do tej grupy odbiorców z produktem i usługą, jaką jest opaska życia (Kilian i in., 2018, s. 147). Rozwiązanie pozwala jednocześnie na udzielenie niezbędnej pomocy najsłabszym jednostkom i działa na rzecz poprawy jakości życia całej społeczności - poprzez wzrost poziomu bezpieczeństwa społecznego, rozumianego jako wspólna troska o ogół obywateli danej społeczności.

Na przykładzie projektu „Małopolski Tele-Anioł” autorzy przedstawili sposób wdrażania nowych rozwiązań w teleopiece. Jest to obecnie jedno z największych tego typu przedsięwzięć realizowanych w Polsce. Ze względu na pilotażowy charakter rozwiązanie to powinno być obiektem dalszych, bardziej wnikliwych badań, pozwalających na sformułowanie wniosków odnośnie potencjalnej replikacji wybranej metody świadczenia usług społecznych - teleopiekuńczych. Być może projekt ten w przyszłości pozwoli na sformułowanie przynajmniej częściowej odpowiedzi na pytanie: „jak” powinny być realizowane usługi społeczne na rzecz osób starszych, w realiach niekorzystnej sytuacji demograficznej i braku wsparcia wynikającego ze zmieniających się kulturowo relacji i funkcji oraz kształtu rodziny (GUS, 2019, s. 141-150).

\section{Literatura}

Ciura, G., Szymańczak, J. (2012). Starzenie się społeczeństwa polskiego. Biuro Analiz Sejmowych, 12(126), 1-4.

Chmielewski, M., Daab, M., Miśkowiec, A., Rogalska, E., Wąsowicz, T. (2017). System usług dla osób niesamodzielnych w celu wsparcia ich samodzielności w miejscu zamieszkania. Usługi dla osób starszych z wykorzystaniem nowych technologii w obszarze społecznym. Warszawa: PCG Polska.

Deloitte (2015). Teleopieka i telemedycyna. Case study - przykłady zastosowań w Wielkiej Brytanii. Londyn: Deloitte Consulting.

Drucker, P.F. (1992). Innowacja i przedsiębiorczość. Praktyka z zasady. Warszawa: Polskie Wydawnictwo Ekonomiczne. 
Flew, T., Cunningham, S., Bruns, A., Wilson, J. (2008). Social Innovation, User-Created Content and the Future of the $A B C$ and SBS as Public Service Media. Submission to Review of National Broadcasting (ABC and SBS), Department of Broadband, Communications and the Digital Economy. Pobrane z: https://eprints.qut.edu. au/16948/1/16948.pdf (dostęp: 21.10.2019).

Glapiński, A. (2012). Schumpeterowska teoria przedsiębiorcy, czyli skąd się bierze pies. Konsumpcja i Rozwój, $1(2), 3-12$.

GUS (2019). Sytuacja demograficzna Polski do 2018 r. Tworzenie i rozpad rodzin. Warszawa: Główny Urząd Statystyczny.

Kilian, J., Ćwirlej-Sozańska, A., Wiśniowska-Szurlej A., Pawlak, K., Sozański, B., Wilmowska-Pietruszyńska, A. (2018). Teleopieka jako skuteczne rozwiązanie w obliczu zjawiska wzrastającego zapotrzebowania na opiekę długoterminową. Niepełnosprawność - zagadnienia, problemy, rozwiązania, I(26), 145-161.

Knop, L., Szczepaniak, M., Olko, S. (2014). Innowacje społeczne w kreatywnej Europie w perspektywie Strategii Europa 2020. Zeszyty Naukowe Politechniki Ślaskiej. Seria Organizacja i Zarzq̨dzanie, 73, 239-253.

Kwaśnicki, W. (2014). Jak wspierać rozwój innowacji społecznych? W: A. Olejniczuk-Merta (red.). Innowacje społeczne od idei do upowszechniania efektu (s. 27-43). Warszawa: Instytut Badań Rynku, Konsumpcji i Koniunktur.

Łódź - Miasto (Tele)Opieki (n.d.), HRP Group. Pobrane z: http://hrp.com.pl/projekty/Imto/\#opis-projektu (dostęp: 12.12.2019).

Małopolski Tele-Anioł (n.d.). Małopolska, Pobrane z: www.malopolska.pl/teleaniol (dostęp: 17.12.2019).

Mulgan, G. (2006). The process of social innovation. Innovations: Technology, Governance Globalization, 1(2), $145-162$.

Mulgan, G., Pulford, L. (2011). Study on Social Innovation for the Bureau of European Policy Advisors. London: The Young Foundation.

Murray, R., Caulier-Grice, J., Mulgan, G. (2010). The Open Book of Social Innovation. London: The Young Foundation, NESTA.

OECD (2008). Podręcznik Os/o: Zasady gromadzenia i interpretacji danych dotyczących innowacji. Wydanie trzecie. Warszawa: Ministerstwo Nauki i Szkolnictwa Wyższego.

Olejniczuk-Merta, A. (2013). Innowacje społeczne. Konsumpcja i Rozwój, 1(4), 21-34.

Pawlińska-Chmara, R., (2016). Teleopieka - wyzwanie i system wzmocnienia bezpieczeństwa dla samorządów w opiece nad osobą starszą. Studia Ekonomiczne. Wydawnictwo Uniwersytetu Ekonomicznego w Katowicach, 290, 149-157.

Phills J.A. Jr., Deiglmeier K., Miller D.T. (2008). Rediscovering Social Innovation. Stanford Social Innovation Review, 6(4), 34-43.

Program "Usługi społeczne dla mieszkańców Poznania” (2017), Poznań: Pobrane z: www.poznan.pl/mim/ngo/ news/program-uslugi-spoleczne-dla-mieszkancow-poznania,102066.html (dostęp: 10.12.2019).

Schumpeter, J.A. (1960). Teoria rozwoju gospodarczego. Warszawa: Polskie Wydawnictwo Ekonomiczne.

Sempruch, G. (2012). Innowacje społeczne - innowacyjne instrumenty polityki społecznej w projektach finansowanych ze środków europejskiego funduszu społecznego. Zarzadzanie publiczne, 2(18), 33-45. doi:10.4467/ 20843968zp.12.009.0533.

Sobol, E. (1997). Słownik wyrazów obcych. Warszawa: Polskie Wydawnictwo Naukowe.

Usługi zdrowotne dla mieszkańców Bytomia z wykorzystaniem nowoczesnych technologii (n.d.). Bytom, Pobrane z: http://teleopieka.bytom.pl/ (dostęp: 10.12.2019).

Wójcik, P. (2013). Znaczenie studium przypadku jako metody badawczej w naukach o zarządzaniu. E-mentor, 1(48). Pobrane z: www.e-mentor.edu.pl/artykul/index/numer/48/id/983 (dostęp: 08.10.2019).

Wronka-Pośpiech, M. (2015). Innowacje społeczne - pojęcie i znaczenie. Studia Ekonomiczne. Zeszyty Naukowe Uniwersytetu Ekonomicznego w Katowicach, 212, 124-136.

Wyrwa, J. (2014). Innowacje społeczne w teorii i praktyce. Warszawa: Polskie Wydawnictwo Ekonomiczne.

Yin, R. (2009). Case study research: design and methods. Thousand Oaks, CA: Sage.

Z@OPIEKOWANI - kompleksowe wsparcie osób niesamodzielnych w m. st. Warszawie (2017). Warszawa. Pobrane z: https://senioralna.um.warszawa.pl/ZAOPIEKOWANI (dostęp: 10.12.2019). 


\section{The "Małopolska Tele-Angel”. A case of social innovation in the area of telehealth home care services for seniors}

Summary: The purpose of the paper is to present innovation in telehealth home care services system applications for seniors, co-created by non-governmental organizations. On the example of the "Małopolski TeleAngel" project, authors present the potential of third sector organizations to be used in the process of providing social services. Based on available project documentation we develop a descriptive case study analysis of telehealth home care services for seniors, co-provided by nongovernmental organizations and co-implemented by the local government. Based on the analysis of actions taken in this area in Poland using the funds available under the Regional Operational Programs for 2014-2020, one specific example was chosen, which stands out due to its scale. The issue of roles and tasks in the process of assessing this service for institutions representing various sectors, including NGO's, was presented. This project is an argument in favour of extending the use of a non-governmental organization in the process of servicing social services.

Keywords: social innovation; telecare; SOS bracelet; NGOs; non-governmental organizations; social services; seniors JEL codes: $\mathrm{H75}$; O35

\section{Informacje o autorach}

\section{Monika Wilk}

Fundacja Małopolski Fundusz Ekonomii Społecznej ul. Rakowicka 14b, 31-510 Kraków e-mail: monikawilk01@gmail.com

\author{
Michał Żabiński* \\ ORCID: 0000-0002-8786-3719 \\ Katedra Zarządzania Organizacjami Publicznymi \\ Kolegium Gospodarki i Administracji Publicznej \\ Uniwersytet Ekonomiczny w Krakowie \\ ul. Rakowicka 27, 30-510 Kraków \\ e-mail: michal.zabinski@uek.krakow.pl \\ * autor korespondencyjny
}

Źródło finansowania badań: Publikacja została dofinansowana sfinansowana ze środków subwencji przyznanej Uniwersytetowi Ekonomicznego w Krakowie.

\section{Prawa autorskie i licencja / Copyright and License}

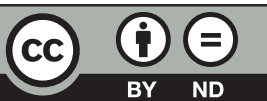

Użycie niekomercyjne - Bez utworów zależnych 4.0 Międzynarodowe (CC BY-ND 4.0) http://creativecommons.org/licenses/by-nc-nd/4.0/deed/pl

This work is published under the terms of the Creative Commons Attribution - NoDerivetives International (CC BY-ND 4.0) License http://creativecommons.org/licenses/by-nc-nd/4.0

Wydane przez Uniwersytet Ekonomiczny w Krakowie. Małopolska Szkoła Administracji Publicznej

Published by Cracow University of Economics - Krakow, Poland. Małopolska School of Public Administration of the Cracow University of Economics 